\title{
Assault on Self: Intimate Partner Abuse and the Contestation of Identity
}

\author{
Jacquelyn Allen-Collinson \\ University of Bath
}

\begin{abstract}
The complexities of intimate partner abuse and violence have been studied from a range of theoretical, conceptual, and methodological perspectives. It is argued here that symbolic interactionist analyses offer specific and powerful insights into this particular interactional domain. This article is based on data generated by a topical life-history case study of a well-educated, middle-class, middle-aged man, whose wife subjected him to sustained unilateral violence and abuse, resulting in deleterious consequences for his health and well-being. Data were gathered via a series of in-depth interviews and a personal diary. The analysis draws on Goffman's conceptualization of "possessional territory" as one of the "territories of the self," in order to examine the role of possessions in the interactional routines of intimate partner abuse.

Key words: intimate partner abuse, domestic violence, abused men, possessional territory, Erving Goffman
\end{abstract}

\begin{abstract}
She is now holding the guitar by its neck, like an axe, threatening to hit him with the body of the thing. In an instant she has let go a full force and powerful blow with the guitar. This catches the edge of his elbow bone but the full force is taken on his upper arm. There is a searing pain. It feels like his bone is broken.... She hits him around the head, knocking off his glasses ...
\end{abstract}

This entry is extracted from the diary of a white, senior-level manager, British man, who charted systematically for two years the abuse and violence to which he was subjected by his wife. The abuse lasted over twenty years, escalating in frequency and severity, prompting several unsuccessful attempts to leave. Finally, the abuse became so overwhelming and its consequences for health and well-being so detrimental that the husband was forced permanently to flee the family home with only a handful of possessions. He made the diary available to me as part of a qualitative research project on accounts of intimate partner abuse and violence (IPA\&V).

Direct all correspondence to Jacquelyn Allen-Collinson, Department of Education, University of Bath, Claverton Down, Bath BA2 7AY, United Kingdom; e-mail: J.Allen-Collinson@bath.ac.uk.

Symbolic Interaction, Vol. 34, Issue 1, pp. 108-127, ISSN 0195-6086, electronic ISSN 1533-8665. (C) 2011 by the Society for the Study of Symbolic Interaction. All rights reserved. Please direct all requests for permission to photocopy or reproduce article content through the University of California Press's Rights and Permissions website, at http://www.ucpressjournals.com/reprintinfo.asp. DOI: 10.1525/si.2011.34.1.108. 
In combination with five in-depth interviews with this male survivor, the diary provides the topical life-history data on which this article is based. Alongside the physical violence, his wife also meted out sustained psychological abuse and subjected to intense contestation her husband's personal identity as a competent, hardworking husband and father. This included attacks on his "extended self" (Belk 1988) in the form of his personal possessions.

There is a myriad of different approaches-substantive, theoretical, and methodological-in the literature on intimate abuse. The focus of my study is a relatively underresearched aspect of IPA\&V-the processes of identity construction and confirmation in everyday life, specifically in the materialistic domain. Goffman's (1972) concept of possessional territory is particularly apposite in analyzing this element within an abusive relationship. To situate the topical life-history analysis, reference is also made to other research on both male and female victims of IPA\&V, where appropriate. The article provides a symbolic interactionist-inspired analysis of the use of objects and possessions in intimate partner abuse, from the perspective of the abused. Thus, it should be emphasized, it is the male victim's perspective and meanings that I seek to convey (for female perpetrators' accounts of committing intimate violence, see, e.g., Miller and Molloy 2006). As is usually the case with research on violence and abuse, I was not able to gain access to the abuser herself, given that the paramount ethical concern was for the anonymity and safety of my informant. His wife had subjected him to violent retribution previously, on learning of any disclosure of "private troubles" to an outsider, and would most likely have attacked him had she become aware of his participation in the research, even after their separation.

Although female-on-male IPA\&V may be constructed as unusual, or even "bizarre" within many mainstream media representations, the research data provide a very different picture as to its mundane character. A brief contextualization of research findings may be helpful in situating the data. In the United States, for example, data from the National Violence Against Women Survey reveal that almost one in four women and one in thirteen men report being "raped and/or physically assaulted by a current or former spouse, cohabiting partner, or date at some time in their lifetime" (Tjaden and Thoennes 2000:iii). Further, as Frias and Angel (2007:1284) note, self-reports of violence probably generate an underestimate of the actual incidence of violence against women because of the stigma often associated with such violence. This similarly applies to reporting by males, given the particular social shame and humiliation, even punishment, attached to being cast as a domestically abused man (George 1994,2002). A study of male victims by Gadd et al. (2002), for example, found that few men reported their experiences of domestic abuse to the police, and fear of disbelief and lack of service provision were highlighted as key reasons. In addition to the rationales reported by women, for men it might be argued that the requirements of contemporary "hegemonic masculinity" (Connell and Messerschmidt 2005) strongly censure male victimization by women, so that any admission of being beaten up by one's wife is tantamount to admitting that one is not a "real man." As George (2003) also indicates, men's reporting of violence, including abuse within the 
intimate context, may be highly constrained by a milieu of nonacceptance and social exclusion experienced by many victimized males. This can exacerbate the shame and fear of stigmatization so that men (analogously to women) routinely attempt to conceal injuries from others or give false explanations for visible injuries. ${ }^{1}$

There is much debate regarding gender symmetry/asymmetry in the perpetration of IPA\&V (Archer 2000; Fiebert 1997; Kimmel 2002; Johnson 2006; Straus 2006). It may be surprising to some to discover that the vast majority of studies using "unselected samples" find that women and men use similar amounts of physical aggression toward their intimate partners (Graham-Kevan 2007:215), including findings of longitudinal studies (e.g., Moffitt et al. 2001) and those using a meta-analytic framework (e.g., Archer 2000). The overall picture appears to be that women and men, heterosexual, bisexual, lesbian, gay (Island and Letellier 1991; Lockhart et al. 1994; Renzetti and Miley 1996), and transsexual/transsexed (Brown 2007) of any age (Hightower et al. 1999; Loxton et al. 2006), physical ability, socioeconomic class or ethnic background are victims of IPA\&V.

Renzetti (1999) and Fitzroy (2001) call on researchers to address the issue of women's violence in intimate relationships, and a corpus of research is certainly developing (Hanson Frieze 2005). Relatively little qualitative research has to-date focused on the experiences of male victims of IPA\&V, whether heterosexual (Migliaccio 2002), gay, or bisexual (Rowlands 2006). Writing recently, George (2003:40) notes that case analysis of battered husbands is virtually nonexistent in terms of academic, qualitative research on assaulted men. There are some notable exceptions (e.g., Cook 1997; Migliaccio 2001, 2002; Palin-Davies 2006), however, and a substantial collection of Internet accounts (e.g., Fiebert and Gonzalez 2007).

This article adds to the growing qualitative literature on intimately abused men, and addresses at the micro-level a case of female-perpetrated abuse. The need for more in-depth qualitative research of IPA\&V in general has recently been highlighted (DeKeseredy 2006). This is needed to gain detailed and accurate understandings of the meanings of, and social contexts in which it occurs (Dobash and Dobash 2004; Swan and Snow 2006), and as Pösö, Honkatukia, and Nyqvist (2008:73) neatly phrase it, "to capture the fluid and contextual nature of violence." Such studies are needed to complement quantitative research, where there is often a tendency toward decontextualization of violent acts and how social actors experience and construct the lived reality of locally produced abuse, all key elements within the symbolic interactionist perspective. Taking a postmodern-feminist stance, McHugh, Livingston, and Ford (2005) remind us of the complexities of conceptualizing women's interpersonal violence. Utilizing an interactionist lens can likewise highlight the complex, multifaceted, and dynamic aspects of IPA\& $\mathrm{V}$, and the importance of contextualizing intimate violence, in this case perpetrated by an abusive woman.

Here I focus the analysis at the micro-level of the everyday, however "risky" that everyday may be (Scott Jones and Raisborough 2007), and enter, theoretically speaking, into the social world of an intimate relationship characterized by unilateral violence. Specifically, I examine the use of material objects within an abusive 
relationship where the husband experienced intense identity contestation via his possessional territory, in addition to sustained physical violence perpetrated by his wife. From an interactionist perspective, Perinbanayagam (2000) reminds us that "identity work" incorporates a strong materialist dimension, in the form of materialistic identification, for example, in the clothes we wear, the cars we drive, and the personal possessions we assemble. The theme of ownership in intimate partner violence remains a relatively underresearched area, which has been addressed qualitatively from a consumer-behavior perspective (Stephens, Hill, and Gentry 2005) but in relation to male-on-female IPV. This article considers the role of possessions in a case of female-perpetrated intimate violence.

In what follows, I describe my research methods, including some of the ethical issues involved in undertaking research on a highly sensitive topic. The interactionist framework relating to identity is described, together with Goffman's conceptual framework relating to possessional territory. The data are then portrayed. Here I use the term intimate partner abuse (IPA) to refer to any abusive act deemed to have the intention, or perceived intention, of generating fear, deliberately disorientating, causing physical injury, intimidation, denigration or emotional pain to the intimate partner. Intimate partner violence (IPV) is used to refer to any act deemed to have the intention or perceived intention of causing physical injury to the intimate partner. IPA\&V combines both elements.

\section{METHODS}

\section{Limited Topical Life History}

Although the case study approach has limitations with regard to generalizability and representativeness, it nevertheless enjoys a long-established and respected record within qualitative research generally (Yin 1984), ethnography, and also within feminist research (Reinharz 1992). Questions arise as to what the "case" in question actually is, ${ }^{2}$ and as Ragin (1992:2) reminds us, "virtually every social scientific study is a case study or can be conceived as a case study. ... At a minimum, every study is a case study because it is an analysis of social phenomena specific to time and place." To take this to the level of the individual, Stake (1995) points out that the case study may be focused on a phase or segment of an individual's life history. The life-history approach in general is particularly well-suited to analyzing the nexus of social structures and personal experiences, and to discovering the "confusions, ambiguities and contradictions played out in everyday experiences" (Plummer 2001:40). In addition to the generation of theoretical insights, Atkinson (1998) contends that a life story can be as valuable an experience for the person narrating as it is for the researcher. Here, it is more accurate to term my approach a "limited topical life history" (Ward 1999), given the focus on a specific element (IPA\&V) in a particular period of an individual's life. The research is thus based on the victim's diary, together with the transcripts of five in-depth interviews with him (lasting between one and two hours each), which together provide the data for the current article. 
The diary was written over a period of two years toward the end of the marriage, during which time the abuse was actually taking place. The reasons for initiating the diary keeping are discussed below. Delamont (1992) emphasizes the symbolic significance of pseudonym choice, and the participant, $\mathrm{NH}$, selected his own. The diary was written primarily at NH's workplace for security reasons. He lived in what became an increasingly abusive relationship for over twenty years, including marriage and the birth of children, before deciding to leave only at a point when he felt in danger of permanent injury from his wife's violence and had assured himself as far as possible that she would not abuse their children. He had previously made several attempts over the years to leave, as do many victims (see Cluss et al. 2006), but his wife had always tracked him down and "persuaded" him to return with threats (largely regarding denial of access to their children), but also with promises that things would improve, this latter being a common narrative of abusers. These threats and promises, together with NH's love for his children, and his enduring optimism that things would eventually work out, were his primary reasons for remaining in the marriage. NH also explained that he came from a very loving and stable family background, where the traditional norms and expectations were that marriage was indeed for life. Both his parents and he himself thus felt that ending the marriage would constitute "failure" on his part. In common with other male victims of partner abuse (see, e.g., Migliaccio 2002), it also emerged from the data that he had largely played down the extent and degree of the violence and its corporeal consequences, repeatedly telling himself that he was strong and could cope.

These factors all contributed to NH's "vocabulary of motive" (Mills 1940:904; Scully and Marolla 1984) for remaining in an unhappy marriage and trying his utmost to make things work, particularly given the centrality of his masculine identification as husband, father, and "provider" for his family. ${ }^{3}$ The concept of a vocabulary of motive delineates how social actors seek to explain (both retroactively and proactively) unanticipated, untoward, or norm-broaching behavior via "accounts" that provide socially valorized rationales for their behavior. As Firth (1995) notes, "accounting" may also be undertaken multilaterally. Within the interactionist framework, too, the actor's definition of reality and the contextualization of the behavior are of course salient features. Although it might at first consideration be thought "extreme" for a person to endure such an abusive and violent marital context for such an extended time, the research evidence indicates that for many victims the abusive relationship continues into old age (Hightower et al.1999).

In the final year of the diary, the text is supplemented by photos, some taken by $\mathrm{NH}$ with his home webcam when alone, and others by his brother on NH's visits to the former's home (some two hundred miles away); together these provide a graphic record of a range of facial and corporeal injuries. Initially, NH informed only his immediate family of his wife's violence, although he did subsequently consult his general medical practitioner and also a marriage guidance counselor. In the final year of the relationship, work colleagues also witnessed the violence at his workplace. Even after he had left the relationship, security personnel had to be called to evict his wife 
from the premises when she made threatening visits. NH explained in the interviews that the motivation for commencing the diary was to enable him to "get a grip on things in my mind" and to "set things down factually" so that he could at least temporarily bracket the fear, humiliation, and distress and try to "get on with the rest of my life." Writing the diary was therefore both cathartic and a coping mechanism. $\mathrm{NH}$ also clarified that he composed the diary entries in the third person, in a "matter of fact" style, finding it too emotionally charged to write in the first person. Subsequently, in an interview he explained that these techniques enabled him to bring to bear some analytic distance on a highly stressful situation.

\section{Data Analysis, Representation, and Ethical Concerns}

Both the personal diary and interview transcripts were read and reread as part of a lengthy process of data immersion and "indwelling" (Maykut and Morehouse 1994), seeking empathic understanding of lived experiences. Observations about the diary and interviews were noted in analytic-memo form. This aided efforts at boundary maintenance between empathic understanding and a wish to avoid colonization of my participant, thus seeking a dialogical research relationship (Frank 2005; Smith et al.2009). Using thematic content analysis and sensitizing concepts derived from the literature, the principal emergent themes were identified, interrogated, compared, and contrasted. For the purposes of this article, the focus on specific interactional instances necessarily makes it less of a narrative-analytic account and more of a "modified realist tale" (Sparkes 2002), which has the effect of fragmenting the diary's endogenous narrative flow. Despite some limitations, the realist tale has certain advantages and is well-suited in this instance for connecting "theory to data in a way that creates spaces for participant voices to be heard in a coherent text" (p. 55). Extracts from the personal diary are reproduced verbatim with explanatory comments added in brackets where necessary.

As Ellis and Bochner (2000) note, in telling their stories people make judgments about how best to present self-relevant facts, and such efforts regarding "presentation of self" (Goffman 1974) apply to NH's interview and diary narratives, as of course to all social research. Indeed, in this form of qualitative research, insistence on an overly rigid (neo)realist ontological and/or epistemological stance is problematic. As Warrington (2001:367) notes, questions of "validity" often arise in the context of qualitative research of this nature, and in common with her, I too believe that my participant was telling me the truth. This was borne out by similarities with other research accounts, by internal consistencies within and between the interviews and the diary, and also in relation to accounts by professional workers involved with IPA \&V. As with most research into IPA\&V, it is a unilateral account to which the researcher has access, and this should be borne in mind. There are of course important issues about the ethics of representing one person through the eyes and interpretations of another, which confront all researchers whose data are based on accounts and narratives (Gilbert and Abell 1983; Allen-Collinson and Hockey 2008). 
The ethical issues involved in researching IPA\&V are certainly acute (Langford 2000), and my paramount concerns were threefold: informant safety, protection of anonymity and confidentiality, and the minimization of distress. Information relating to specialist victim-support services was made available prior to the interviews. The research was approved by the relevant university authorities, and all audio and digital recordings were transcribed by me to ensure confidentiality. Pseudonyms are used throughout, and I have also sought to remove identifying characteristics from the quotations included. I remain immensely grateful for the courage and openness of my informant, for as Owens (2006:1171) reminds us: "Resisting abuse, even years after the fact by speaking it aloud, is an act of bravery for a person who has been forcibly taught to surrender authority." The social agency of victims/survivors must also be fully acknowledged, and it became clear from the interviews that $\mathrm{NH}$, in common with other survivors, did not "surrender" authority, but that this was subject to ongoing contestation.

\section{THEORETICAL PERSPECTIVES: IDENTITIES AND IDENTITY WORK IN IPA\&V}

Symbolic interactionism, with its interest in the social actor, meanings, context, and everyday experience, offers a powerful lens through which to view IPA\&V, refracted both via the perpetrator (e.g., Goodrum, Umberson, and Anderson 2001) and via the victim (e.g., Lempert 1994), including the latter's reasons for leaving or indeed repeatedly returning to a violent partner (Chang 1989). While multistranded, symbolic interactionism in general acknowledges both social agency and the social forces shaping and constraining social action, so that social behavior is theorized as both structurally constrained and actively constructed (Allen-Collinson and Hockey 2007), although there are divergences in the primacy accorded to agency and structure by different theorists. Denzin (1984) has analyzed negative symbolic interaction within domestic violence and how narrative construction allows the individuals involved to capture the meanings given to their lives. The very act of constructing a narrative can be seen as a component of "identity work." Although there is not the space here to address the complexities of current sociological debates around identities or indeed around "narrative identities/selves" (Smith and Sparkes 2008), key to my analysis are interactionist concepts of self and identity as processual, situationally contingent, interactional accomplishments between the social actor and others, particularly significant others such as an intimate partner. Identities are thus relational.

Although open to different interpretations and debate, a distinction is often made between social and personal identities. For Snow and Anderson (1995) who take a symbolic interactionist stance, social identities are those we attribute or impute to others, situating them as social objects. Personal identities refer to the meanings attributed to the self by the social actor and actively brought into play during the interactional flow. Further, personal and social identities may be inconsistent and, as Walseth (2006:76) emphasizes, under constant challenge and attack. Such attacks 
were of narrative salience both in NH's personal diary and in the interviews, where it emerged that he engaged in various forms of "intensive remedial identity work" (Lutgen-Sandvik 2008:98) in relation to material objects such as cherished musical instruments. This was to counterbalance his wife's assault on his personal identity, by focusing on elements of his identity viewed as "separate" and predating his marital relationship. Here I examine assaults on personal possessions as an extension of personal identity, in Goffman's (1972) terms "possessional territory." Although Goffman himself may have disputed such a label, Denzin (1992:10) terms him a "third-generation interactionist," and his work, I contend, offers conceptual insights that can profitably be applied to the interactional routines of IPA\&V. His study of the "territories of the self," for example, in Relations in Public (1972:50-87), together with their potential violation via contaminative acts, is highly pertinent to the current analysis. In Relations in Public, Goffman posits various territories of the self, including possessional territory, as discussed in detail below (for an analysis of intrusion on, and contamination of, other territories of the self in intimate abuse, see Allen-Collinson 2009a).

The next sections are structured as follows. First, I portray the normalization and routinization of intimate violence in NH's own relationship and situate this within the wider research literature. This section introduces interactionist concepts germane to the article and also provides details of NH's relationship context, where his wife's violence constituted part of a long-term, regular pattern of abuse-the "intimate terrorism pattern of abuse" identified by Johnson and Ferraro (2000), in contrast to more sporadic, angry outbursts. I then briefly examine the strategies NH adopted to cope with the negative symbolic interaction endemic within his marriage. Subsequently, I analyze the contestation of NH's extended self in the form of his possessional territory along three specific dimensions: clothing, symbolic possessions, and official documentation.

\section{Normalization and Routinization of IPA\&V}

The research on intimate violence often indicates a patterning. Walker (1985), for example, proposes a cycle of violence comprising three distinct phases, varying in time and intensity: tension building, acute battering, and "loving," contrite behavior. With the exception of the latter phase (although some "making up" did occur, as described below), this kind of cycle was clearly apparent to $\mathrm{NH}$, who indicated in the interviews that he recognized a routine patterning in his marital relationship. Such patterning is also revealed throughout the diary, as typified by an entry that follows a violent attack by his wife:

"Get out of the house" is her intended final gesture for the beginning of his day. He explains that he has agreed to take their daughter to school, and she is not yet ready to go. "Then wait in the car" she concludes, throwing his briefcase out of the front door. He tries to explain that he feels it is unfair that he should have to wait in the car just because she wants him out of the house.... She hits him around the head twice before thumping him in the stomach, winding him. The pattern is 
established. From her first overture in the bathroom, he knew that he was going to be hit by her before he left the house. (my emphasis)

The routinization and normalization of IPV by both victims and perpetrators figure prominently in research studies. Smartt and Kury (2007), for example, reported that a 1998 UK survey found that one in five young men and one in ten young women aged thirteen to nineteen considered violence against women to be acceptable. In relation to the nonreporting of "domestic incidents," alarmingly, Stanko (1985:48) indicates that abuse is often characterized by female victims as the " normal" interaction of intimate couples." This taken-for-grantedness, routinization, and acceptance also emerge in the accounts of male victims (Migliaccio 2002). The abuser too may rationalize or deny the seriousness of her or his actions, redefining the situation to disparage the pain, injury, and distress caused. In the interviews, $\mathrm{NH}$ indicated that his wife would exonerate herself to their two children by saying: "Mummy only hits Daddy because he argues with her," or would chide him with: "it's only a scratch," or "just tickling," as recorded in the diary:

She scratches him down the right cheek with her finger nails [drawing blood]. It feels like burning. "Oh come on" she says "where's your sense of fun-I'm only having a tickle." He holds his cheek with his hand. She spits at him again.

Denzin (1984:506) terms this "paradoxical violence," as it "combines and often confuses (for victims) spurious, accidental, playful, and real violence," simultaneously communicating multiple interactional meanings. So, even as NH's wife inflicted considerable corporeal harm on him, she denied her violent intent, laughing off her actions as mere "fun" and "tickling."

The interactionist conceptualization of role taking is salient here, more specifically "synesic role-taking" (Scully 1988:201), which involves taking the role of the other in the imaginative construction of her or his feelings and attitudes, with the aim of anticipating behavior. In the interviews, NH described how, over the years, he had become adept at identifying his wife's moods, in order to anticipate and avoid violence as the usual sequitur to increasing verbal abuse. Diary entries, too, provide frequent instances of his avoidance tactics, including one Christmas Eve when he arrived home too tired from work to do anything more active to escape his wife's anger than sit in the car:

He brings home the turkey but gets into trouble because there is not the right stuffing at the butcher's. Once home, she tells him to "get out of the house" until 17:30, when her parents are coming round.... He sits in the car on the common for three hours, getting more cold and more tired. What a way to spend Christmas Eve, he thinks.

While attempts at avoiding or minimizing violence may be successful and allow the relationship to continue, they may also at times have the unintended consequence of escalating an attack. A victim in Migliaccio's (2000:34) study, for example, learned that while he could restrain his wife in an attempt to halt the violence, this ultimately proved counterproductive because "the result was ... she escalated." Over the years, $\mathrm{NH}$ had evolved various techniques of managing his own pain, fear, and distress, but 
his very attempts to remain calm often enraged his wife who then meted out further punishment:

When she is attacking him, he often (usually reflexively) tries to calm himself with Buddhist meditation techniques that he is learning. This entails clasping the hands as if in prayer. This infuriates her as she claims that he is being facetious, praying at her. Universally this leads to his being belted again.

This then was the context of NH's marital relationship in which intimate abuse and violence gradually, over the years, became endemic, routine, and even normalized. In between bouts of abuse and violence, however, it became clear from the interviews and also within the diary that periods of relative calm developed. $\mathrm{NH}$ clearly loved his children, and it seemed that happy times spent with the children to some extent counterbalanced and compensated for the unhappiness and stress of his marital relationship.

Some of the principal themes that emerged from NH's account (both in the diary and in the interviews) are now examined in relation to possessional territory. In this case, I identify three forms of such territory: clothing, symbolic possessions, and official identifications. In reality, these categories often overlap but are considered discrete elements here for analytic purposes. The role of possessions in the form of animals_-such as pet or farm animals - as pawns within IPA\&V is not discussed here, as the analysis centers on inanimate objects. ${ }^{4}$

\section{THE MATERIAL REALM: POSSESSIONAL TERRITORY}

Goffman's (1972) concept of possessional territory may be conceptualized as one component of the extended self, a means of physically and symbolically extending the self in the world via specific objects. For Goffman, possessional territory comprises "any set of objects that can be identified with the self and arrayed around the body wherever it is" (p. 62). Here I apply his conceptual frame to the interactional domain of IPA\& $\mathrm{V}$, where victims often report having their possessions violated by an abuser (Stephens et al.2005), which can be conceptualized as an act of violence on the self. In terms of such attacks, a stark diary list records NH's personal items destroyed or seriously damaged by his wife, within just a two-month period: "radio, alarm clock, shaver, mobile 'phone, calculator, mail, Studio Mixer [expensive item of equipment for audio mixing and editing of music recordings], six shirts, his glasses (several times)." A further diary entry provides more detail as to one particular attempt to destroy a work mobile phone within the "normal" interactional routines of his marriage:

Another normal day. Another row leading quickly to violence. She throws his briefcase around and kicks it repeatedly (as well as thumping him). She snaps the aerial of his mobile phone (which belongs to his employers), which cannot be replaced as it is an integrated unit. He has an identical old phone with no SIM card in it. He swaps the SIM card and the face of the 'phone from new to old. One new 'phone is made out of two deficient ones. She then finds the "good" phone and promptly throws it in the bin without telling him (underneath some vegetable 
peelings). He then gets aggression [verbal abuse] from her for making a mess on the floor trying to retrieve his phone from the bin.

\section{Clothing}

Contestation of NH's materialistic identification appears to have commenced early in his intimate relationship, as the diary prologue describes. When moving into his home initially on a short-term basis, his (future) wife effected major changes to both his house and his garden, without seeking permission and often against his stated wishes, while he was at work:

She was assertive (change the house around, change the garden, ceremoniously burn all his underwear because she didn't like it, and by 1983 , move to a larger house). On their first date, she opened the door of her flat to him and whilst asking him to wait on the doorstep, went to get a replacement tie because she did not like his. (diary prologue)

Her attempts to control the very clothing he wore, it emerged from the interview data, subsequently became routine. Such controlling behavior has consequences for self-identity, for as Stone (1977:101-2) suggests, "as the self is dressed, it is simultaneously addressed, for, whenever we clothe ourselves, we dress 'toward' or address some audience whose validating responses are essential to the establishment of our self." So, if an individual constantly contests and criticizes rather than validates a partner's dress, she or he is contesting a key element of her or his materialistic identification. Clothing constitutes part of the body "sheath" in Goffman's (1972:62) terms, and its subjection to violence may be perceived in some instances as akin to an attack on the victim's actual body. Destruction of clothing features in many accounts of IPA, as exemplified by one of Mullaney's (2007) interviewees, a man who had his bags packed ready to leave permanently when his wife took all his clothes and threw them over the front yard, battering him as she did so. In the interviews, $\mathrm{NH}$ recounted how shirts constituted a favored target for his wife's violence, as they were easy to rip to pieces. A diary entry indicates the destruction of two in the space of just two days:

She grabs his shirt to pull him into the kitchen.... She pulls the front of the shirt with such force that it actually tears right down the front.... She has shredded the whole thing. He moves to go upstairs but she grabs his testicles with force. This is agony for a moment.... The following morning is more of the same. She tightens his tie like a noose and then pulls the neck button off completely, ripping the area around the button. He has to wear another one to work. She hits him several times and he just makes for the door.

\section{Symbolic Possessions}

Symbolic (as opposed to more functional) possessions-those cherished and of sentimental value-are central to materialistic identification. As Belk (1988) notes, symbolic possessions hold emotional significance for their owners/users, distinct 
from their utilitarian function. Consequently, disdainful treatment of cherished possessions can be particularly poignant for victims of IPA. Stephens et al. (2005) found that possessions symbolic of attachments to people other than the spouse/partner are particularly likely targets for destruction. NH recorded in the diary his accidental discovery in the rubbish bin of an item his wife knew to be of sentimental value and had attempted secretly to throw out:

He found his favourite DIY shirt in a plastic bag in the bin. It originally had been given to him as a gift by the students at the University of A ... where he had externally examined. It had some sentimental value, but it had been binned [trashed] without consultation.

As the diary and transcripts reveal, personal items of sentimental value were frequently and deliberately thrown out by his wife without permission or even discussion. In one diary instance of many, his wife denied all knowledge of some missing personal documents (to which only she and $\mathrm{NH}$ had access) and which $\mathrm{NH}$ later found thrown in a rubbish bin:

He moved the top set of rubbish to find all of his Buddhist papers. In addition he found the whole contents of his "personal and private" box file. All of his memories-letters from school chums, student cards, old postcards etc-all ceremoniously binned. More upsettingly, his parents had given him a copy of their Will two years before, and she had binned that as well.

While deeply hurt and angered by this behavior, $\mathrm{NH}$ explained in the interviews that, had he protested more vigorously, this would undoubtedly have "provoked" a physical attack from his wife and served to escalate the violence.

Central to an individual's materialistic identification are those objects representing personal talents and interests that provide potent testimony of her or his autonomy, skill, and creative being-in-the-world. An abuser may consequently find this evidence particularly threatening to her or his attempts at "coercive control" (Stark 2006) of a victim. An interviewee in Stephens et al.'s (2005:50) study attested to the importance of her materialistic identification as a prolific artist:

This is the hardest thing. I paint; I had almost a thousand pieces of artwork....He destroyed them.... I did a painting that was not one of my better ones. It was a blond woman.... and I came back one day, and it was slashed and had heel marks.

Similarly, as a musician and composer, NH had accumulated an extensive collection of his own songs, written and recorded over several decades. He recounted in the interviews how his wife often violently trashed both his recording equipment and the actual recordings. A diary entry notes the sudden disappearance of over a hundred of his recorded songs from a room to which only he and his wife had access. He explained in an interview that the songs were never found, and a diary entry refers to the incident:

He has about 100 songs that he has written over the years, nearly all recorded on tape or cassette. He finds an old tape recorder and records all of them on to CDs so that they will no longer deteriorate. There are four full CDs of his songs 
(which she has always told him are "crap") dating from the age of 16 . He places them in his CD rack in the study. Within four weeks they all have disappeared. He asks her if she has seen them. "Are you accusing me of stealing them?" is her only reply.

Silver (1996) has highlighted the importance of personal objects, standing as critical testimony about the self during role transitions, invested with meanings that give coherence to people's lives. Analogously, Noble and Walker (1997) emphasize the role of objects as symbolizing attachment to previous biographical stages. As a musician, NH's instruments were invested with deep symbolic meaning, which his wife seems to have known well. He would try to escape from the unhappiness and stresses of his marriage by creating music, to provide comforting biographical continuity with happier times. In the interviews, $\mathrm{NH}$ explained how his wife scathingly criticized his music and regularly attacked him with his own guitars and other instruments, the symbolic violence of which was not lost on either party. In the diary, in an act replete with both symbolic and physical violence, his wife used a long-cherished guitar dating back to his teenage years to attack him, as illustrated in the opening quotation, the precursor to which was this interactional exchange:

"What the bloody hell do you think you are doing?" "I'm playing my guitar," is his response. "Don't be so f__ ing facetious." She lunges at him and wrenches his guitar from him. The strap cuts into his shoulder but soon she has the whole thing from him. "I will not tolerate this behaviour from you." She is now holding the guitar by its neck, like an axe, threatening to hit him with the body of the thing...

Such use of personal possessions physically to abuse and injure literally adds insult to injury and is particularly poignant when such objects are normally imbued with positive cathexis. Indeed the very threat of damage to cherished symbolic possessions may be sufficient to force a person into submission, as graphically illustrated in Stephens et al.'s (2005:51) study, where one husband would threaten to smash up his wife's beloved possessions until she begged him and "grovelled at his feet," promising to do anything he wanted if only he would desist from "hurting" the object.

Analogously, the rejection or ejection of treasured, symbolic possessions from one's home can be hurtful, as well as signifying contestation of the other's aesthetic judgment in the case of paintings and other objets d'art. Goode (2007) evocatively recounts such hurtful behavior in relation to the paintings and personal collections she had assembled during her marriage and which were then subject to acrimonious contestation upon divorce. Such objects can be invested with a cargo of symbolic meanings. NH's diary recounts how a gift from an influential "guru" figure was treated with disdain by his wife, who refused to have it in their home:

The guru thanked him $[\mathrm{NH}] \ldots$ and presented him with a picture in thanks. ... This was a thoughtful presentation. Firstly, the picture was painted by X ... himself and secondly it was of a place that [he] knew had a special significance for him. He was really touched. On taking the picture home and showing it to her, she felt that it was not a good picture at all and she would not have it hanging in the house. "It came from work," she said, "keep it at work." 
Symbolic possessions that represent attachments to significant others may also be deliberately damaged or destroyed by abusers. For NH, this included not only gifts from family, friends, and work colleagues but also photographic records of these relationships, such as pictures of friends and relatives, and even photographs of him accompanied by other conference delegates or colleagues, as he explained in an interview:

I had an old photograph of me with X [a leading academic] taken at a conference years ago in Iceland when I was just starting out. It was an old favourite photo with me and a group of people at the College and X and it had special memories. One day when I came to look through for some photos, I noticed it—and a lot of others-were missing. I asked [his wife] if she'd seen it. "Oh, I threw a lot of your old photos out," she said. "You don't need them now."

\section{Official Identifications}

Beyond the domestic milieu, an abuser may also seek to control a partner and curtail her or his agency in the occupational and public domains, via the destruction or concealment of official material identifications necessary to confirm status, such as a birth certificate, social security card, or credit cards. The interview transcripts and diary detail a plethora of attempts to misappropriate or destroy such documents (and refusal to admit to knowledge of their whereabouts), including the "vanishing" of NH's passport, regularly required for business purposes:

Whilst on holiday, he checks [for] his passport. He always keeps it in his briefcase ... but his wife has always said that she should keep it with the other family passports. It is missing from his briefcase when he goes to look. He asks his wife if she has seen it. She does not say yes or no.

Items central to NH's autonomy as an adult and also to his occupational identity were particularly prone to destruction or confiscation; credit cards, car keys, and his briefcase were all snatched from him one frosty morning when he was in a hurry to get to work:

He is up at 7:00 and on his way downstairs to the car... She is up and pulling at his lapels again, cricking his neck. He gets to the car and is cleaning the screen with his credit card. She is out now, takes his card from him, takes the keys from the ignition and takes his brief case. He will not be allowed to go to work until he apologises [for what, he never knew-as explained in an interview].

Toward the end of the relationship, even NH's house keys were taken by his wife, with an aggressive refusal to return to them so that he was unable to have duplicates made. This prevented him from freely entering and leaving his own home, thereby not only functionally constraining him and causing considerable inconvenience but also symbolically reducing him to pre-adult status.

The above instances represent just some of the catalog of challenges to NH's materialistic identification made by his wife, in both the domestic context and also in the wider public world. NH described how his wife regularly damaged or destroyed a gamut of possessions, from the small, such as mobile phones and eyeglasses (without which he could not drive or read), to the larger scale, such as guitars, expensive 
recording-studio equipment, a bike rack, and his car. As a postscript, in terms of "identity talk" or "vocabularic identification" (Perinbanayagam 2000), it is interesting to note that $\mathrm{NH}$ rarely used the term victim in the interviews, and it does not appear once in his diary, despite the fact that sustained and serious physical abuse was perpetrated on him. "Victim" for him connoted negative identification" and a challenge to his masculine identity (Allen-Collinson 2009b). Further, with regard to his social agency, and as noted above, $\mathrm{NH}$ emphasized that his reasons for staying so long in the abusive relationship included his enduring belief that things would improve, that it was his "duty" to stay and make the marriage work (divorce representing personal "failure"), and that he was afraid his wife would try to deny access to their children if they did separate. This latter fear turned out to be well-founded as subsequent to their separation and divorce, she made strenuous attempts to prevent him seeing their two children, and even threatened to take them abroad permanently to make access difficult, if not impossible.

\section{CONCLUSION}

This article contributes original research findings to the literature in three principal ways. First, it makes an empirical contribution to the growing literature on male victims and survivors of IPA\&V via a topical life-history of an abused man. Second, it develops an underresearched area within studies of intimate abuse by shifting the analytic focus to the materialistic dimension of IPA, in particular, the role played by personal possessions. Third, the article takes forward interactionist theory, in a small way, by applying Goffman's work to a new area: the contested possessional terrain of IPA. As the analysis here is based on a topical life history, the study makes no claims for generalizability or representativeness of findings; these were not its purpose. Similarities with findings of other research on abused men and women did become evident, however, and linkages are highlighted in the preceding sections.

The role played by possessions in identity maintenance and contestation emerged as salient within the study. If indeed possessions constitute an integral part of the extended self, as has been theorized, then violence toward highly cherished and symbolic possessions may well be experienced as a violation of the individual. For, as Stephens et al. (2005:41) contend, "If indeed certain possessions are parts of our self-identity, their involuntary loss should lead to a diminution of sense of self." Such arguments are certainly substantiated by the qualitative data from this case study. As NH recounted in the interviews, attacks on and destruction of his cherished possessions were indeed experienced as personal violations. He felt increasingly that any possession toward which he exhibited a degree of attachment was likely to be damaged, destroyed, defiled (Allen-Collinson 2009a), thrown out, or literally used as a weapon against him.

Interestingly, Stephens et al. (2005) argue that physical abuse has increasingly moved from the private to the public domain in the past three decades, with regard to attempts to destroy not only possessions but also work identity. This argument is certainly supported by NH's narratives, as his wife was increasingly liable to contest and 
seek to undermine his occupational identity, both by invading his physical workplace and also via nuisance phone calls to him, his colleagues, and managers. Given that, by choice, NH's wife hardly ever worked, and then only for very short periods of time (because, she said, she "got bored with work"), he was the primary wage earner and economic "provider" throughout their relationship, even when the children were of school age and not requiring full-time care.

This "traditional" gender division of labor, while his wife's choice, may have led to resentment of NH's success at work (judging by comments made in the interviews). It may partly explain why she sought to exert control over this particular domain of his life and to undermine his masculine identification (Allen-Collinson 2009b) both via contestation of his occupational credibility and also within the domestic sphere in his role as a father and "breadwinner." It may at first appear to an "outsider" somewhat illogical for NH's wife to risk losing her husband and his economic resources by such abusive and violent behavior, although such "illogicality" is similarly highlighted in other research (e.g., Migliaccio 2002). As far as could be ascertained from the interviews, she was sufficiently confident of NH's loyalty, commitment, and dedication to his children, together with the level of her control over him, that this "risk" was written off against her desire to exert increasing control over all areas of his life. Furthermore, she came from a wealthy family background and had access to funds from private sources, which she did not share with her husband.

In relation to the further applicability of Goffman's work, the research also found that contaminative processes-both corporeal and of possessions-used within IPA\&V were analogous to some of the "mortification processes" that Goffman (1976) identified so vividly as operating within total institutions (see Allen-Collinson 2009a). In his discussion of the "territories of the self," Goffman (1972) makes a final general point about territoriality. The respect shown for the territories of the self, including a person's possessions, is, Goffman contends, "somehow central to the subjective sense that the individual has concerning his [sic] selfhood, his ego, the part of himself with which he identifies his positive feelings" (p. 82). Routine and explicit disrespect for and violation of such territory may thus be regarded in many ways as an assault on selfhood. In this case, $\mathrm{NH}$, as a survivor of such assaults, reported that along with the extensive physical harm and corporeal injuries he endured, the effects of his wife's regular encroachments on, contamination, and destruction of his possessional territory were certainly experienced as traumatic and very real violations of the self.

Finally, for those unfamiliar with the research on IPA\&V, it might be thought that the case study research portrayed here represents a rare and extreme occurrence in terms of extent and longevity of the abuse, and in relation to the gender of perpetrator and victim. Sadly and depressingly, the research evidence confirms that this is by no means an exceptional case. In "Western" societies, as indicated in the introduction, IPA\&V are routinely committed by men and women, of all sexualities, across all socioeconomic classes and ethnic groups, and at all stages of the life course. In addition to the research based on self-reports from victims and perpetrators, an extensive body of research with police officers, legal workers, social workers, health 
professionals, and within the criminal justice system (e.g., DeLeon-Granados, Wells, and Binsbacher 2006) also testifies to the widespread nature of IPA\&V perpetrated by both women and men. This case study has provided an analytic glimpse at the micro-level into the everyday lived realities of one man's experiences in an intimate relationship in which IPA\&V were regular and routine, and the everyday was indeed "troubling and troubled" (Scott Jones and Raisborough 2007:1).

Acknowledgments: The author wishes to thank the editor and the four anonymous reviewers for their constructive comments on an earlier draft, and most of all $\mathrm{NH}$ who so generously gave his time to share in detail such painful experiences.

\section{NOTES}

1. For an extended discussion of abused men and hegemonic masculinity, see Allen-Collinson 2009b.

2. For a detailed discussion of what constitutes the "case," see the edited collection by Ragin and Becker (1992).

3. For an extended discussion in relation to masculinity, see Allen-Collinson 2009b.

4. For a discussion of the use of animals within intimate violence, see Ascione 1997.

5. For an excellent analysis of the gender dimensions of narrative reframing of victimization, see de Welde 2003.

\section{REFERENCES}

Allen-Collinson, J. 2009a. "Intimate Intrusions Revisited: A Case of Intimate Partner Abuse and Violations of the Territories of the Self." Qualitative Sociology Review 5(1):50-69. .2009b. "A Marked Man: A Case of Female-Perpetrated Intimate Partner Abuse." International Journal of Men's Health 8(1):22-40.

Allen-Collinson, J. and J. Hockey. 2007. "'Working Out' Identity: Distance Runners and the Management of Disrupted Identity." Leisure Studies 26(4):381-98. . 2008. "Autoethnography as 'Valid' Methodology? A Study of Disrupted Identity Narratives." International Journal of Interdisciplinary Social Sciences 3(6):209-17.

Archer, J. 2000. "Sex Differences in Aggression between Heterosexual Partners: A Meta-Analytic Review." Psychological Bulletin 126:651-80.

Ascione, F. R. 1997. Battered Women's Reports of Their Partners' and Their Children's Cruelty to Animals. Journal of Emotional Abuse 1(1):119-33.

Atkinson, R. 1998. The Life Story Interview. Thousand Oaks, CA: Sage.

Belk, R. W. 1988. "Possessions and the Extended Self." Journal of Consumer Research 15:139-68.

Brown, N. 2007. "Stories from Outside the Frame: Intimate Partner Abuse in Sexual-Minority Women's Relationships with Transsexual Men." Feminism and Psychology 17(3):373-93.

Chang, B. K. 1989. "An Abused Spouse's Self-Saving Process: A Theory of Identity Transformation." Sociological Perspectives 32(4):535-50.

Cluss, P. A., J. C. Chang, L. Hawker, S. Hudson Scholle, D. Dado, R. Buranosky, and S. Goldstrohm. 2006. "The Process of Change for Victims of Intimate Partner Violence: Support for a Psychosocial Readiness Model.” Women's Health Issues 16:262-74.

Connell, R. W. and J. W. Messerschmidt. 2005. "Hegemonic Masculinity: Rethinking the Concept." Gender and Society 19(6):829-59.

Cook, P. W. 1997. Abused Men: The Hidden Side of Domestic Violence. Westport, CT: Praeger.

DeKeseredy, W. S. 2006. "Future Directions." Violence against Women 12(11):1078-85. 
Delamont, S. 1992. Fieldwork in Educational Settings: Methods, Pitfalls, and Perspectives. Lewes, UK: Falmer.

DeLeon-Granados, W., W. Wells, and R. Binsbacher. 2006. "Arresting Developments: Trends in Female Arrests for Domestic Violence and Proposed Explanations." Violence against Women 12(4):355-71.

Denzin, N. K. 1984. "Toward a Phenomenology of Domestic, Family Violence.” American Journal of Sociology 90(3):483-513.

- 1992. Symbolic Interactionism and Cultural Studies: The Politics of Interpretation. Oxford: Blackwell.

De Welde, K. 2003. "Getting Physical: Subverting Gender through Self-Defense." Journal of Contemporary Ethnography 32(3):247-78.

Dobash, R. P. and R. E. Dobash. 2004. "Women's Violence to Men in Intimate Relationships." British Journal of Criminology 44:324-49.

Ellis, C. and A. Bochner. 2000. "Autoethnography, Personal Narrative, Reflexivity: Researcher as Subject." Pp. 733-68 in Handbook of Qualitative Research, edited by N. K. Denzin and Y. S. Lincoln. 2nd ed. Thousand Oaks, CA: Sage.

Fiebert, M. S. 1997. "Annotated Bibliography: References Examining Assaults by Women on Their Spouses/Partners." Pp. 273-86 in Sexual Harassment and Sexual Consent, edited by B. M. Dank and R. Refinette. Vol. 1. New Brunswick, NJ: Transaction.

Fiebert, M. S. and D. M. Gonzalez. 2007. Battered Men-the Hidden Side of Domestic Violence: Latest Research Findings. Retrieved January 13, 2009, from http://www.batteredmen.com/ gjdvstor.htm.

Firth, A. 1995. “'Accounts' in Negotiation Discourse: A Single-Case Analysis." Journal of Pragmatics 23(2):199-226.

Fitzroy, L. 2001. "Violent Women: Questions for Feminist Theory, Practice, and Policy." Critical Social Policy 21(1):7-34.

Frank, A. 2005. "What Is Dialogical Research and Why Should We Do It?" Qualitative Health Research 15(7):964-74.

Frias, S. M. and R. J. Angel. 2007. "Stability and Change in the Experience of Partner Violence among Low-Income Women." Social Science Quarterly 88(5):1281-306.

Gadd, D., S. Farrall, D. Dallimore, and N. Lombard. 2002. Domestic Abuse against Men in Scotland. Edinburgh: Scottish Executive.

George, M. J. 1994. "Riding the Donkey Backwards: Men as the Unacceptable Victims of Marital Violence." Journal of Men's Studies 3(2):137-59. 2002. Skimmington Revisited. Journal of Men's Studies 10(2):111-27. 2003. "Invisible Touch." Aggression and Violent Behavior 8:23-60.

Gilbert, G. N. and P. Abell, eds. 1983. Accounts and Action: Conference Proceedings. Surrey Conferences on Sociological Theory and Method. Aldershot, UK: Gower.

Goffman, E. 1972. Relations in Public: Microstudies of the Public Order. Harmondsworth, UK: Penguin. - 1974. The Presentation of Self in Everyday Life. Harmondsworth, UK: Penguin. . 1976. Asylums: Essays on the Social Situation of Mental Patients and Other Inmates. Harmondsworth, UK: Penguin.

Goode, J. 2007. "Whose Collection Is It Anyway? An Autoethnographic Account of 'Dividing the Spoils' upon Divorce." Cultural Sociology 1(3):365-82.

Goodrum, S., D. Umberson, and K. Anderson. 2001. "The Batterer's View of the Self and Others in Domestic Violence.” Sociological Inquiry 71(2):221-40.

Graham-Kevan, N. 2007. "Domestic Violence: Research and Implications for Batterer Programmes in Europe." European Journal of Criminal Policy Research 13:213-25.

Hanson Frieze, I. 2005. "Female Violence against Intimate Partners: An Introduction." Special issue, Psychology of Women Quarterly 29(3):229-37.

Hightower, J., M. J. Smith, C. A. Ward-Hall, and H. C. Hightower. 1999. "Meeting the Needs of Abused Older Women? A British Columbia and Yukon Transition House Survey." Journal of Elder Abuse and Neglect 11:39-58. 
Island, D. and P. Letellier. 1991. Men Who Beat the Men Who Love Them. New York: Harrington Park.

Johnson, M. P. 2006. "Conflict and Control: Gender Symmetry and Asymmetry in Domestic Violence." Violence against Women 12(11):1003-18.

Johnson, M. P. and K. J. Ferraro. 2000. "Research on Domestic Violence in the 1990s: Making Distinctions." Journal of Marriage and the Family 62(4):948-63.

Kimmel, M. S. 2002. “'Gender Symmetry' in Domestic Violence: A Substantive and Methodological Research Review." Violence against Women 8(11):1331-63.

Langford, D. R. 2000. "Pearls, Pith, and Provocation: Developing a Safety Protocol in Qualitative Research Involving Battered Women." Qualitative Health Research 10(1): 133-42.

Lempert, L. B. 1994. "A Narrative Analysis of Abuse: Connecting the Personal, the Rhetorical, and the Structural." Journal of Contemporary Ethnography 22(4):411-41.

Lockhart, L. L., B. W. White, V. Causby, and A. Isaac. 1994. "Letting Out the Secret: Violence in Lesbian Relationships." Journal of Interpersonal Violence 9(4):469-92.

Loxton, D., M. Schofield, R. Hussain, and G. Mishra. 2006. "History of Domestic Violence and Physical Health in Midlife." Violence against Women 12(8):715-31.

Lutgen-Sandvik, P. 2008. "Intensive Remedial Identity Work: Responses to Workplace Bullying, Trauma and Stigmatization." Organization 15(1):97-119.

Maykut, P. and R. Morehouse. 1994. Beginning Qualitative Research: A Philosophical and Practical Guide. London: Falmer.

McHugh, M. C., N. A. Livingston, and A. Ford. 2005. "A Postmodern Approach to Women's Use of Violence: Developing Multiple and Complex Conceptualisations." Psychology of Women Quarterly 29(3):323-36.

Migliaccio, T. A. 2001. "Marginalizing the Battered Male." Journal of Men's Studies 9(2):205-26.

—. 2002. "Abused Husbands: A Narrative Analysis." Journal of Family Issues 23(1):26-52.

Miller, S. L. and M. L. Molloy. 2006. "Women's Use of Force: Voices of Women Arrested for Domestic Violence." Violence against Women 12(1):89-115.

Mills, C. W. 1940. "Situated Actions and Vocabularies of Motive." American Sociological Review 5:904-9.

Moffitt, T. E., A. Caspi, M. Rutter, and P. A. Silva. 2001. Sex Differences in Antisocial Behavior. Cambridge: Cambridge University Press.

Mullaney, J. L. 2007. “Telling It Like a Man: Masculinities and Battering Men's Accounts of Their Violence." Men and Masculinities 10(2):222-47.

Noble, C. H. and B. A. Walker. 1997. "Exploring the Relationships among Liminal Transitions, Symbolic Consumption, and the Extended Self." Psychology and Marketing 14(1):29-47.

Owens, E. 2006. "Conversational Space and Participant Shame in Interviewing." Qualitative Inquiry 12(6):1160-79.

Palin-Davies, S. 2006. Male Victims of Female-Perpetrated Domestic Violence. Norwich, UK: University of East Anglia.

Perinbanayagam, R. S. 2000. The Presence of Self. Oxford: Rowman and Littlefield.

Plummer, K. 2001. Documents of Life-2: An Invitation to a Critical Humanism. London: Sage.

Pösö, T., P. Honkatukia, and L. Nyqvist. 2008. "Focus Groups and the Study of Violence." Qualitative Research 8(1):73-89.

Ragin, C. C. 1992. "Introduction: Cases of 'What Is a Case'?" Pp. 1-17 in What Is a Case: Exploring the Foundations of Social Inquiry, edited by C. C. Ragin and H. S. Becker. Cambridge: Cambridge University Press.

Ragin, C. C. and H. S. Becker, eds. 1992. What Is a Case: Exploring the Foundations of Social Inquiry. Cambridge: Cambridge University Press.

Reinharz, S. 1992. Feminist Methods in Social Research. New York: Oxford University Press.

Renzetti, C. M. 1999. "The Challenge to Feminism Posed by Women's Use of Violence in Intimate Relationships.” Pp. 42-56 in New Versions of Victims, edited by S. Lamb. New York: New York University Press. 
Renzetti, C. M. and C. H. Miley. 1996. Violence in Gay and Lesbian Domestic Partnerships. New York: Haworth.

Rowlands, J. 2006. Domestic Abuse among Gay and Bisexual Men: An Exploratory Study in South Wales. Norwich, UK: University of East Anglia.

Scott Jones, J. and J. Raisborough. 2007. "Introduction: Situating Risk in the Everyday.” Pp. 1-18 in Risks, Identities, and the Everyday. Aldershot, UK: Ashgate.

Scully, D. 1988. "Convicted Rapists' Perceptions of Self and Victim: Role Taking and Emotions." Gender and Society 2(2):200-213.

Scully, D. and J. Marolla. 1984. "Convicted Rapists' Vocabulary of Motive: Excuses and Justifications." Social Problems 31(5):530-44.

Silver, I. 1996. "Role Transitions, Objects, and Identity." Symbolic Interaction 19(1):1-20.

Smartt, U. and H. Kury. 2007. "Domestic Violence: Comparative Analysis of German and UK Research Findings." Social Science Quarterly 88(5):1263-80.

Smith, B. and A. C. Sparkes. 2008. "Contrasting Perspectives on Narrating Selves and Identities: An Invitation to Dialogue." Qualitative Research 8(1):5-35.

Smith, B., J. Allen-Collinson, C. Phoenix, D. Brown, and A. Sparkes. 2009. "Dialogue, Monologue, and Boundary Crossing within Research Encounters: A Performative Narrative Analysis." International Journal of Sport and Exercise Psychology 7(3):342-59.

Snow, D. A. and L. Anderson. 1995. "The Problem of Identity Construction among the Homeless." Pp. 239-58 in Symbolic Interaction: An Introduction to Social Psychology, edited by N. J. Hermann and L. T. Reynolds. New York: General Hall.

Sparkes, A. C. 2002. Telling Tales in Sport and Physical Activity. Champaign, IL: Human Kinetics.

Stake, R. E. 1995. The Art of Case Study Research. Thousand Oaks, CA: Sage.

Stanko, E. A. 1985. Intimate Intrusions. London: Routledge and Kegan Paul.

Stark, E. 2006. "Commentary on Johnson's 'Conflict and Control: Gender Symmetry and Asymmetry in Domestic Violence." Violence against Women 12(11):1019-25.

Stephens, D. L., R. P. Hill, and J. W. Gentry. 2005. "Consumer-Behavior Perspective on Intimate Partner Violence." Journal of Contemporary Ethnography 34(1):36-67.

Stone, G. P. 1977. "Appearance and the Self." Pp. 86-118 in Human Behaviour and Social Processes: An Interactionist Approach, edited by A. M. Rose. London: Routledge and Kegan Paul.

Straus, M. A. 2006. "Future Research on Gender Symmetry in Physical Assaults on Partners." Violence against Women 12(11):1086-97.

Swan, S. C. and D. L. Snow. 2006. "The Development of a Theory of Women's Use of Violence in Intimate Relationships." Violence against Women 12(11):1026-45.

Tjaden, P. and N. Thoennes. 2000. Extent, Nature, and Consequences of Intimate Partner Violence. Washington, DC: National Institute of Justice and Centers for Disease Control.

Walker, L. E. 1985. "Psychological Impact of the Criminalization of Domestic Violence on Victims." Victimology 10:281-300.

Walseth, K. 2006."Young Muslim Women and Sport:The Impact of Identity Work." Leisure Studies 25(1):75-94.

Ward, K. J. 1999. "The Cyber-Ethnographic (Re)construction of Two Feminist Online Communities." Sociological Research Online 4. Retrieved April 7, 2008, from http://www.socresonline. org.uk/archives.html.

Warrington, M. 2001. "I Must Get Out': The Geographies of Domestic Violence." Transactions of the Institute of British Geographers 26:365-82.

Yin, R. K. 1984. Case Study Research: Design and Methods. Newbury Park, CA: Sage. 